\title{
Survival, reproductive development and density of tillers in pure swards of Aries HD and Yatsyn 1 perennial ryegrass (Lolium perenne)
}

\author{
S.J. BLUETT ${ }^{1}$, J. HODGSON ${ }^{1}$, P.D. KEMP ${ }^{1}$ and T.N. BARRY ${ }^{2}$ \\ ${ }^{1}$ Institute of Natural Resources, Massey University, Palmerston North \\ ${ }^{2}$ Institute of Food, Nutrition and Human Health, Massey University, Palmerston North
}

\begin{abstract}
Tiller number, survival and development were determined in clover-free swards of Aries HD and Yatsyn 1 high-endophyte perennial ryegrass established in the autumn of 1995 and continuously stocked with sheep. Few tillers died until mid December, after which survival approximated an exponential decay curve. There was no difference in the rate of tiller death between Aries HD and Yatsyn 1 swards. Seedheads were first observed on 19 November 1996 and were still visible on 26 March 1997. Aries HD appeared to have a greater proportion of initial reproductive tillers, but after mid-December a lower proportion than Yatsyn 1. There was an indication that Aries HD swards had a higher density of lighter tillers than Yatsyn 1. In a second experiment established in the autumn of 1997 rotationally grazed with sheep, Aries HD appeared to have a greater proportion of vegetative tillers during November and December, and greater mean ryegrass tiller density. Marginal differences in reproductive behaviour were not translated into any difference in in vitro organic matter digestibility between Aries HD and Yatsyn 1.
\end{abstract}

Keywords: Aries HD, digestibility, flowering, perennial ryegrass (Lolium perenne), tiller demography, tiller population density, tiller survival, Yatsyn 1

\section{Introduction}

Aries HD perennial ryegrass was bred specifically for improved whole plant digestibility over the summer and autumn period (November to February). Plant material for the breeding program originated from the Waikato. Wrightson Seeds have demonstrated a slightly higher organic matter digestibility (2.6\%) for Aries HD over Yatsyn 1 from herbage samples cut to grazing height every 4 weeks and allowed to regrow (Wrightson Seeds Ltd 1995), however it was not known which component of morphology or phenology contributed to this effect. In this experiment Yatsyn 1 derived from the Mangere ecotype (Thom et al. 1998) was used as the standard perennial ryegrass cultivar.
In previous work (Bluett 1999) the proportion of leaf was significantly greater in Aries HD than in Yatsyn 1 pasture over September to November, perhaps reflecting a different rate of tiller maturity. Nevertheless, the greater leaf content of the Aries HD pasture was not reflected in a higher herbage digestibility. A tiller demography experiment was carried out to compare the patterns of reproductive development and tiller survival between Aries HD and Yatsyn 1 in pure swards at Massey University from 3 September 1996 to 26 March 1997.

\section{Materials and methods}

\section{Tiller demography experiment}

Clover-free swards of Aries HD and Yatsyn 1 highendophyte perennial ryegrass were established in the autumn of 1995, in a randomised complete block design with three 0.33 ha plots per treatment, which were continuously stocked with ewes and lambs (3 September to 5 November 1996) or weaned lambs (5 November to 25 March 1997), to maintain a mean sward height of $6 \mathrm{~cm}$. Measurements of adult ryegrass tillers (150 per treatment) began on 4 September 1996 and finished on 26 March 1997. The proportion of tillers infected with endophyte was over $80 \%$ in both cultivars (Bluett 1999). Information on liveweight gain, herbage intake and grazing behaviour from ewes and suckling lambs over spring, and from weaned lambs over summer (Bluett 1999) is reported elsewhere.

\section{Tiller demography}

Five transects, each $1 \mathrm{~m}$ long, were randomly placed in each plot. Wooden pegs were placed at each end to aid relocation of transects. Ten tillers spaced at $10 \mathrm{~cm}$ intervals along each transect were identified with a brightly coloured plastic tie, and tiller survival and reproductive development were recorded at weekly intervals. Vegetative tillers were classified as dead when they were brown and withered, and as reproductive tillers when the defoliated stem was brown and sapless (Korte et al. 1985).

Tiller survival or longevity was expressed as the ratio of surviving tillers to the initial number of tagged tillers, using equation (1) (Korte 1986). 
Survival $=\mathrm{N}_{\mathrm{t}} /\left(\mathrm{N}_{0}-\mathrm{m}\right)$

where $\left(\mathrm{N}_{0}-\mathrm{m}\right)$ was the initial number of tillers $(50 /$ plot) corrected for the number of missing tillers on that measurement day, and $\mathrm{N}_{\mathrm{t}}$ was the number of tillers alive on that measurement day.

Reproductive development was expressed as the ratio of flowering tillers (with a visible seedhead) to the initial number of tillers at the beginning of the experiment, corrected for missing tillers, using Equation (2). Reproductive development was also expressed as the ratio of newly elongating tillers or newly flowering tillers to the number of live tillers from the previous measurement date, using equation (3).

Reproductive development $=\mathrm{N}_{\mathrm{t}} /\left(\mathrm{N}_{0}-\mathrm{m}\right)$

Reproductive development $=\mathrm{Nr}_{(\mathrm{t})} /\left(\mathrm{N}_{(\mathrm{t}-1)}-\mathrm{m}\right)$

Where $\left(\mathrm{N}_{(\mathrm{t}-1)}-\mathrm{m}\right)$ was the number of live tillers from the previous measurement day corrected for missing tillers, and $\mathrm{Nr}$ (t) the number of newly elongating or flowering tillers.

Tiller population density, tiller weight and ryegrass leaf percentage

Tiller population density was calculated from 40 pasture cores per plot, each $50 \mathrm{~mm}$ in diameter, taken at random, and the number of ryegrass and other species (predominantly Poa annua) tillers/core recorded (Mitchell \& Glenday 1958). Ryegrass tillers from cores were bulked, oven-dried at $80^{\circ} \mathrm{C}$ for 24 hours and weighed to determine mean tiller dry weight. Ground level herbage samples were also taken fortnightly, and live ryegrass was separated into leaf lamina and stem for estimation of ryegrass leaf percentage.

\section{Statistical analysis}

Analysis of variance was carried out on plot mean values with three replicates, using the General Linear Models (GLM) procedure of SAS (SAS Institute Inc. 1988).

\section{Rotational grazing experiment}

Clover-free swards of Aries HD and Yatsyn 1 were established in the autumn of 1997, in a randomised complete block design with six replicate plots $(0.2 \mathrm{ha} /$ plot). Plots were rotationally grazed with mobs of sheep on each cultivar in a leader-follower sequence (28-day regrowth period). Samples of 300 ryegrass tillers per plot were cut at random to ground level before grazing and were recorded as vegetative or reproductive (exhibiting stem elongation), and then the proportion of vegetative tillers calculated. Tiller population density was determined before grazing (Mitchell \& Glenday
1958). Ground level herbage samples were also collected for dissection into ryegrass leaf lamina and stem for estimation of ryegrass leaf percentage. The proportion of tillers infected with endophyte was $96 \%$ in both cultivars (Bluett 1999).

\section{Statistical analysis}

Analysis of variance and repeated measures analysis were carried out with pairs of plots as replicates, using the General Linear Models (GLM) procedure of SAS (SAS Institute Inc. 1988).

\section{Results}

\section{Tiller demography experiment}

\section{Tiller survival}

Few tillers died until 11 December 1996, after which survival approximated an exponential decay curve (Figure 1). The exponential decay model $\left(\mathrm{e}^{\mathrm{bt}}\right)$ was a good fit to the data, and the mean curve for both cultivars explained $97 \%$ of the variation in tiller survival from this data. Regression coefficients and coefficients of determination $\left(\mathrm{R}^{2}\right)$ for this model are given in Table 1. The constant (b) is the rate of tiller death. Constant $\mathrm{b}$ was converted to a half-life $\left(\mathrm{T}_{1 / 2}\right)$, the time taken for half the tillers to die as defined by Korte (1986). There was no significant difference between rate of tiller death (b) in Aries HD and Yatsyn 1 swards (Table 1).

Table 1 Rate of tiller death (regression coefficient, b), coefficient of determination $\left(R^{2}\right)$, and half-life $\left(T_{1 / 2}\right)$ of tillers for Aries $H D$ and Yatsyn 1 perennial ryegrass under continuous stocking management in 1996/97, and for Grasslands Nui in summer 1978 (Korte 1986).

\begin{tabular}{lccc}
\hline Cultivar & Rate of tiller death $(\mathrm{b})$ & $\mathrm{R}^{2}$ & Half life $\left(\mathrm{T}_{1 / 2}\right)$ \\
\hline Aries HD & -0.0129 & 0.909 & 53 \\
Yatsyn 1 & -0.0136 & 0.959 & 51 \\
Mean & -0.0133 & 0.986 & 52 \\
SEM & 0.00162 & - & - \\
P & 0.87 & - & - \\
Grasslands Nui & -0.0124 & 0.961 & 56 \\
\hline
\end{tabular}

\section{Reproductive development}

Stem elongation was first observed on 6 November and the first seedheads appeared 2 weeks later on 19 November. The proportion of tillers with a seedhead is shown in Figure 2. The mean proportion over this period was 0.081 for Aries HD and 0.114 for Yatsyn 1, but this difference was not significant (SEM $= \pm 0.1007$, $\mathrm{P}>0.4$ ). Aries HD appeared to have a greater proportion of flowering tillers until 19 December and then a lower proportion than Yatsyn 1 after January, although no 
difference was statistically significant. The development of newly flowering tillers expressed as a proportion of the number of live tillers from the previous measurement day is shown in Figure 3. There was no overall difference between Aries HD and Yatsyn 1 swards in the proportion of newly elongating tillers $(0.122$ vs $0.154 \pm$ $0.0245, \mathrm{P}>0.1$ ), or in the proportion of newly flowering tillers $(0.027$ vs $0.040 \pm 0.0263$, $\mathrm{P}>0.3$ ) expressed in this way. The total percentage of tillers initially tagged that subsequently elongated was $62 \%$ and the total percentage of tillers observed with a seedhead was $24 \%$ in both Aries HD and Yatsyn 1 swards.

Tiller population density, tiller weight and ryegrass leaf percentage

Ryegrass tiller population density increased from October to January, then decreased to March (Table 2). Change in tiller density over time was significant $(\mathrm{P}<0.05)$. Poa annua was a major (but similar) weed contaminant in both cultivars (10 560 vs $10260 \pm 270$ tillers $/ \mathrm{m}^{2}, \mathrm{P}>0.3$, for Aries HD and Yatsyn 1 tillers). Yatsyn 1 tillers were consistently heavier than Aries HD tillers, although this difference was not significant (Table 2). The percentage of leaf in ryegrass in Aries HD and Yatsyn 1 swards in spring (9 September 1996 to 28 November 1996) was 63 vs $61 \pm 0.7 \%(\mathrm{P}<0.05)$, and in summer $(30$ December 1996 to 27 March 1997) was 73 vs $72 \pm 4.7 \%(\mathrm{P}>0.8)$.

Table 2 Ryegrass tiller population density and tiller weight in swards of Aries HD and Yatsyn 1, under continuous stocking management in 1996/97.

\begin{tabular}{|c|c|c|c|c|}
\hline & \multicolumn{4}{|c|}{ Ryegrass tiller population density (tillers $/ \mathrm{m}^{2}$ ) } \\
\hline & Aries HD & Yatsyn 1 & SEM & $\mathrm{P}$ \\
\hline October & 3158 & 5731 & 275 & 0.39 \\
\hline January & 5034 & 4977 & 866 & 0.97 \\
\hline March & 3075 & 3237 & 249 & 0.69 \\
\hline \multirow[t]{3}{*}{ Mean } & 3755 & 3648 & 480 & 0.81 \\
\hline & \multicolumn{4}{|c|}{------ Ryegrass tiller dry weight (mg) ------ } \\
\hline & Aries HD & Yatsyn 1 & SEM & $P$ \\
\hline October & 7.6 & 8.4 & 0.95 & 0.62 \\
\hline January & 8.0 & 10.3 & 0.60 & 0.12 \\
\hline March & 6.5 & 6.8 & 0.67 & 0.74 \\
\hline Mean & 7.4 & 8.5 & 0.90 & 0.27 \\
\hline
\end{tabular}

\section{Rotational grazing experiment}

The proportion of vegetative tillers from midDecember to mid-January was generally higher in Aries HD than Yatsyn 1 pasture, but this difference was not significant (Figure 4). After
Figure 1 Survival of tillers from 11 December 1996 (day 0) to 26 March 1997 (day 106) under continuous stocking management (see Equation 1). The fitted line $\left(e^{b t}\right)$ has $b=-0.0133$ (the mean of Aries HD ( ) and Yatsyn $1(\boldsymbol{\square}))$.

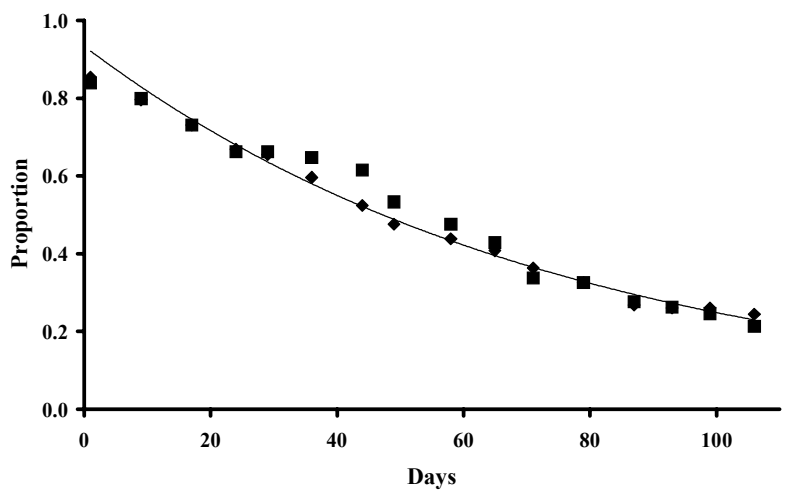

Figure 2 Proportion of tillers with a seedhead, (see Equation 1) for Aries HD $(\bullet)$ and Yatsyn $1(\boldsymbol{\square})$, under continuous stocking management in 1996/97.

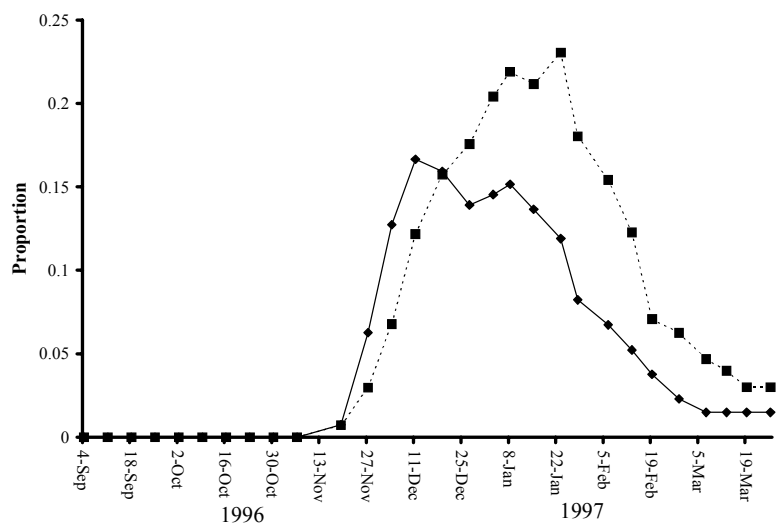

Figure 3 Proportion of new seedheads developing (see Equation 2) for Aries HD $(\bullet)$ and Yatsyn $1(\square)$, under continuous stocking management in 1996/97.

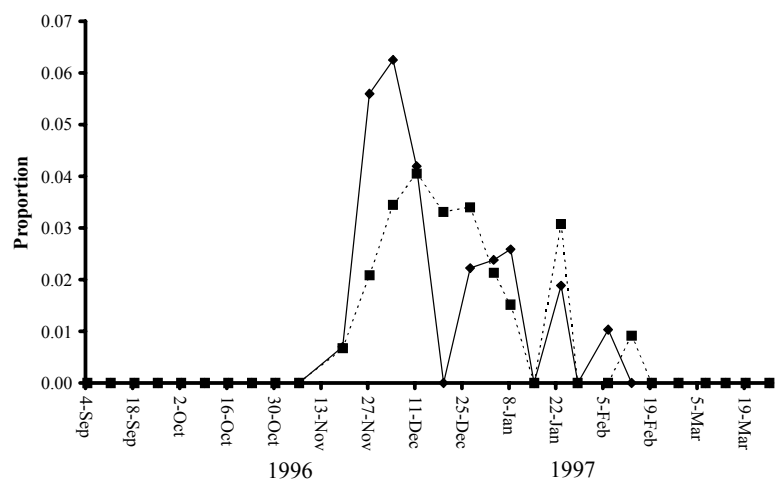


mid-December over $95 \%$ of tillers in both cultivars were vegetative. Ryegrass tiller density was significantly higher in Aries HD than Yatsyn 1 pasture in January (Figure 5) but was not statistically different over the entire experiment $(4580$ vs $3800 \pm 328$ tillers $/ \mathrm{m}^{2}, \mathrm{P}>0.1$ ). Percentage of leaf in ryegrass in Aries HD and Yatsyn 1 swards was 68 vs $69 \pm 4.7 \%(\mathrm{P}>0.6)$.

\section{Discussion}

The main objective of the tiller demography experiment was to determine if there were any differences in the survival of tillers and in the onset, duration and intensity of reproductive development between Aries HD and Yatsyn 1 cultivars, which may cause a difference in organic matter digestibility. Cultivar differences in reproductive growth can result from differences in the proportions of vernalised tillers, the timing of stem elongation, or in the growth rates of reproductive tillers (Hunt \& Mortimer 1982). For example, I. Bahmani (pers. comm.) found that Ellett perennial ryegrass has a higher proportion of reproductive tillers than Grasslands Ruanui. In addition, Matthew (1992) has observed an apparent difference in their seasonal pattern of tiller demography.

Because reproductive tillers die when they reach maturity (Woodward 1998), it would be expected that contrasts in reproductive development would affect the rate of tiller death. However, there were no differences in tiller death rate between the two cultivars. Aries HD and Yatsyn 1 cultivars had similar tiller survival patterns to Grasslands Nui (Table 1). Furthermore, the persistency of Aries HD and Yatsyn 1 perennial ryegrass was found to be similar after a three year mowing trial in the Waikato (NZPBRA 1996).

The percentage of leaf was significantly higher in Aries HD than in Yatsyn 1 swards from September to November. Aries HD began flowering at a similar time as Yatsyn 1 (Figures 2 and 3), suggesting that the difference in leaf content was not due to Aries HD being slower developing than Yatsyn 1. There was no difference in the percentage of leaf over December to March, when lamb performance was the same between the two cultivars (Bluett 1999).

There were no differences in herbage nutritive value between Aries HD and Yatsyn 1 pastures. In vitro organic matter digestibility did not differ between
Figure 4 Proportion of vegetative and reproductive tillers (having a visible seedhead or exhibiting stem elongation) from November to December 1997 in swards of Aries HD and Yatsyn 1 perennial ryegrass, under rotational grazing management.
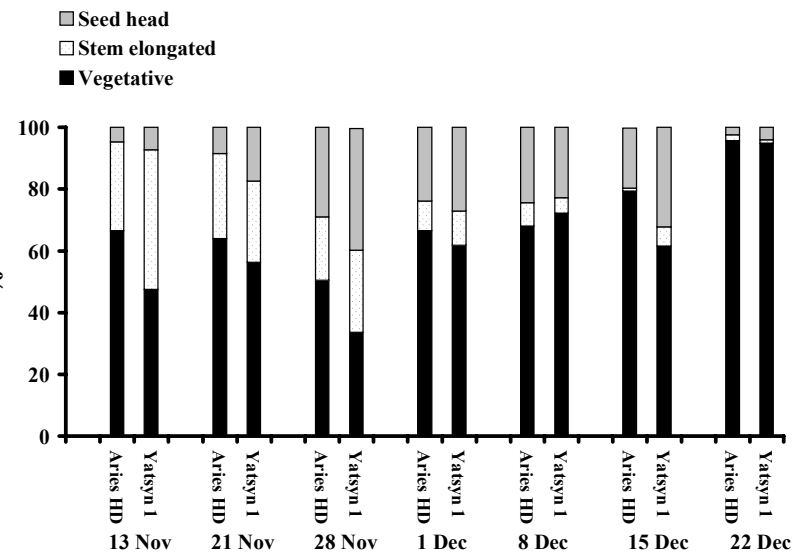

Figure 5 Tiller population density of ryegrass and other species in swards of Aries HD and Yatsyn 1 perennial ryegrass, under rotational grazing management in 1997/98.

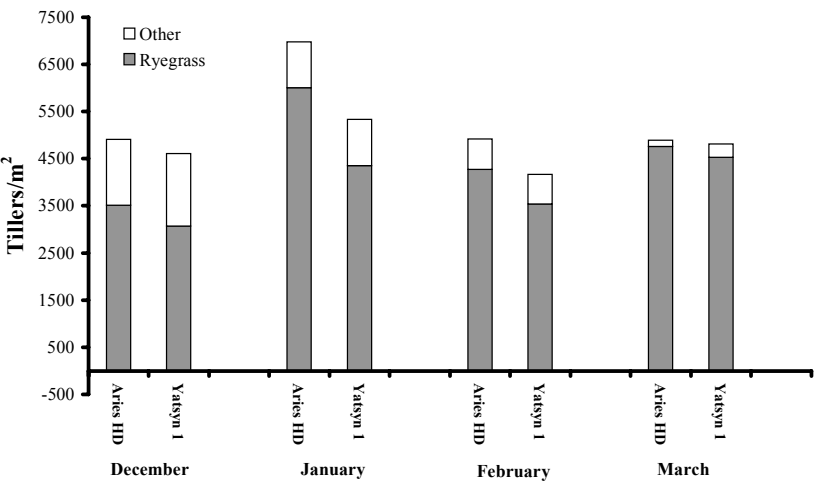

cultivars at any stage during the tiller demography experiment (Bluett 1999) or in previous work (Bluett et al. 1997). Likewise, digestibility was similar between Aries HD and Yatsyn 1 under rotational grazing management (Bluett 1999) from herbage cut to ground level (60.6 vs $60.7 \pm 2.37 \%, \mathrm{P}>0.9)$ and to grazing height ( 66.7 vs $64.0 \pm 2.62 \%, \mathrm{P}>0.6$ ).

Observations on tiller behaviour were made under continuous sheep grazing. This meant that reproductive tillers might have been defoliated before they reached the seedhead stage so they were not included in this category. We assumed that the probability of tillers being grazed was a random effect and equal between plots. Aries HD appeared to have a slightly more rapid onset of inflorescence and then a lower proportion of 
flowering tillers than Yatsyn 1. Korte et al. (1984) observed that most Nui reproductive tillers $\left(2400 / \mathrm{m}^{2}\right)$ appeared in an initial group, with a secondary group of reproductive tillers $\left(1000 / \mathrm{m}^{2}\right)$ appearing during November and December. Aries HD showed a second wave of seedhead production after December 19, while Yatsyn 1 had a more consistent production of seedheads throughout (Figure 3). Aries HD is thought to have lower aftermath heading than Yatsyn 1 (M.N. Norriss, pers. comm.) which is supported to a limited extent by the data in this study. Aries HD appeared to have a lower proportion of tillers elongating than Yatsyn 1. However, the total proportion of tillers becoming reproductive (visible seedhead) was $24 \%$ in both cultivars. Under rotational grazing management Aries HD had a greater proportion of vegetative tillers during November and December (Figure 5), although again this difference was not significant ( 65.9 vs $55.5 \pm 4.70 \%, \mathrm{P}>0.1)$.

Under continuous stocking management Aries HD had slightly lighter tillers (15\%) and on two dates had a higher tiller density than Yatsyn 1 (Table 2), suggesting tiller size/density compensation (Matthew et al. 1996). Under rotational grazing management tiller density was also higher in Aries HD than Yatsyn 1 swards (Figure 5), but in both experiments these differences were not significant overall.

\section{Conclusions}

Aries HD and Yatsyn 1 cultivars had similar tiller survival patterns to those previously reported for Grasslands Nui. Aries HD showed a more rapid onset of initial flowering but then a lower proportion of flowering from secondary reproductive tillers than Yatsyn 1. There is an indication that Aries HD swards have a higher density of finer tillers than Yatsyn 1. Marginal contrasts in reproductive behaviour were not significant, and did not result in any contrast in herbage nutritive value under either continuous stocking or rotational grazing management.

\section{ACKNOWLEDGEMENT}

Funding support from Wrightson Seeds Ltd, Christchurch for this work is acknowledged.

\section{REFERENCES}

Bluett S.J. 1999. An evaluation of the nutritive value and endophyte status of a new perennial ryegrass (Lolium perenne) cultivar (Aries $\mathrm{HD}$ ). $\mathrm{PhD}$ thesis. Massey University.

Bluett, S.J.; Hodgson, J.; Kemp, P.D.; Barry, T.N. 1997. Animal evaluation of Aries HD perennial ryegrass selected for high digestibility. Proceedings of the New Zealand Grassland Association 59: $245-249$.

Hunt, W.F.; Mortimer, B.J. 1982. A demographic analysis of growth differences between Nui and Ruanui ryegrass at high and low nitrogen inputs. Proceedings of the New Zealand Grassland Association 43: 125-132.

Korte, C.J. 1986. Tillering in 'Grasslands Nui' perennial ryegrass swards 2 . Seasonal pattern of tillering and age of flowering tillers with two mowing frequencies. New Zealand journal of agricultural research 29: 629-638.

Korte, C.J.; Watkin, B.R.; Harris, W. 1984. Effects of the timing and intensity of spring grazings on reproductive development, tillering, and herbage production of perennial ryegrass dominant pasture. New Zealand journal of agricultural research 27: 135-149.

Korte, C.J.; Watkin, B.R.; Harris, W. 1985. Tillering in 'Grasslands Nui' perennial ryegrass swards 1. Effect of cutting treatments on tiller appearance and longevity, relationship between tiller age and weight, and herbage production. New Zealand journal of agricultural research 28: 437-447.

Matthew, C. 1992. A study of seasonal root and tiller dynamics in swards of perennial ryegrass (Lolium perenne $\mathrm{L}$.). $\mathrm{PhD}$ thesis. Massey University.

Matthew, C.; Hernandez-Garay, A.; Hodgson, J. 1996. Making sense of the link between tiller density and pasture production. Proceedings of the New Zealand Grassland Association 57: 83-87.

Mitchell, K.J.; Glenday, A.C. 1958. The tiller population of pastures. New Zealand journal of agricultural research 1: 305-318.

New Zealand Plant Breeding and Research Association Inc. 1996. National forage variety trial P293RUA. Unpublished report.

SAS, 1988. SAS user's guide, release 6.03 edition. United States of America, Statistical Analysis System Institute.

Thom, E.R.; Waugh, C.D.; McCabe, R.J. 1998. Growth and persistence of perennial and hybrid ryegrasses when grazed by dairy cows in the central Waikato region of New Zealand. New Zealand journal of agricultural research 41: 477-486.

Woodward, S.J.R. 1998. Quantifying different causes of leaf and tiller death in grazed perennial ryegrass swards. New Zealand journal of agricultural research 41: 149-159.

Wrightson Seeds Ltd 1995. Pasture Options 5. Wrightson Seeds Ltd. 5 pp. 
